\title{
PENGARUH CITRA MEREK, KUALITAS PRODUK DAN PERSEPSI HARGA TERHADAP KEPUASAN DAN NIAT BELI ULANG
}

\author{
Ida Ayu Putu Dian Savitri ${ }^{1}$ \\ I Made Wardana ${ }^{2}$ \\ ${ }^{1,2}$ Fakultas Ekonomi dan Bisnis Universitas Udayana (Unud), Bali, Indonesia \\ e-mail: dayudian25@yahoo.co.id
}

\begin{abstract}
ABSTRAK
Niat beli ulang merupakan salah satu faktor penting bagi perusahaan. Niat beli ulang terhadap suatu produk tersebut timbul karena konsumen merasa puas akan produk yang dibeli sebelumnya. Salah satu kunci dalam menciptakan niat beli ulang adalah dengan meningkatkan kepuasan pelanggan. Penelitian ini dilakukan di Kota Denpasar yang melibatkan 120 responden. Metode purposive sampling dipilih sebagai metode dalam pengumpulan data. Pengumpulan data dilakukan dengan menyebarkan kuesioner yang berisikan pernyataan berkaitan dengan variabel citra merek, kualitas produk, persepsi harga, kepuasan pelanggan dan niat beli ulang. Selanjutnya, data dari hasil pengumpulan kuesioner tersebut diolah dengan menggunakan uji validitas, dan uji reliabilitas untuk mengetahui kelayakan dan konsistensi indikator dalam kuesioner. Selain uji validitas dan uji reliabilitas, dilakukan uji lain yaitu analisis jalur. Hasil dari penelitian ini ditemukan bahwa, citra merek, kualitas produk dan persepsi harga berpengaruh positif dan signifikan terhadap kepuasan pelanggan. Citra merek merupakan variabel yang paling dominan berpengaruh terhadap kepuasan pelanggan. Kepuasan pelanggan juga memiliki pengaruh positif dan signifikan terhadap niat beli ulang. Sehingga dapat disimpulkan bahwa menciptakan niat beli ulang pada konsumen dapat dilakukan dengan meningkatkan kepuasan pelanggan.
\end{abstract}

Kata Kunci: citra merek, kepuasan pelanggan, kualitas produk, persepsi harga, niat beli ulang

\begin{abstract}
Repeat intention is one of the important factors for the company. The re-purchase intention of a product arises because the consumer is satisfied with the product purchased previously. One of the keys in creating a buy-back intention is to increase customer satisfaction. This research was conducted in Denpasar City involving 120 respondents. The purposive sampling method is chosen as the method of data collection. Data collection was done by distributing questionnaires containing statements relating to brand image variables, product quality, price perceptions, customer satisfaction and re-purchase intentions. Furthermore, data from the results of collecting the questionnaire is processed by using the validity test, and reliability test to determine the feasibility and consistency of indicators in the questionnaire. In addition to the validity test and reliability test, another test is performed path analysis. The results of this study found that, brand image, product quality and price perception have a positive and significant impact on customer satisfaction. Brand image is the most dominant variable affecting customer satisfaction. Customer satisfaction also has a positive and significant impact on repurchase intentions. So it can be concluded that creating the intention to buy back on consumers can be done by increasing customer satisfaction.

Keywords: brand image, customer satisfaction, product quality, price perception, retention purpose
\end{abstract}




\section{PENDAHULUAN}

Kosmetik adalah bahan atau sediaan yang dimaksudkan untuk digunakan pada bagian luar tubuh manusia seperti: epidermis, rambut, kuku, bibir dan organ genital bagian luar atau gigi dan mukosa mulut terutama untuk membersihkan, mewangikan, mengubah penampilan, memperbaiki bau badan, melindungi atau memelihara tubuh dalam kondisi baik (BPOM, 2013). Kosmetik merupakan salah aspek yang dapat menunjang penampilan. Pada daerah perkotaan, kosmetik berkembang menjadi sebuah kebutuhan. Demi memperoleh kosmetik dengan kualitas yang baik, masyarakat tidak jarang rela mengeluarkan dana lebih untuk memenuhi kebutuhan akan kosmetik. Tingginya kebutuhan kosmetik ini menjadi peluang bagi produsen kosmetik untuk memasarkan produknya di Indonesia. Data pada Tabel 1 menunjukan perusahaan yang telah memasarkan produk kosmetiknya di Indonesia.

Tabel 1.

Top Brand Award Kategori Perawatan Pribadi Tahun 2018

\begin{tabular}{clrr}
\hline No. & Merek & TBI (\%) & \multicolumn{1}{c}{ Kisaran Harga (Rp) } \\
\hline 1. & Oriflame & 16,8 & $52.000-139.000$ \\
2. & Wardah & 16,4 & $47.000-99.000$ \\
3. & The Body Shop & 12,7 & $200.000-269.000$ \\
4. & Mustika Ratu & 12,5 & $48.000-90.000$ \\
5. & Dove & 11,7 & $73.000-100.000$ \\
\hline \multicolumn{2}{l}{ Sumber: } &
\end{tabular}

Berdasarkan Tabel 1 dapat diketahui produk kosmetik merek Oriflame pada kategori produk Body Butter atau Body Cream memiliki Top Brand Index (TBI) sebesar 16,8\% di Indonesia, angka ini menggambarkan produk kosmetik merek Oriflame merupakan merek dengan tingkat familiaritas yang tertinggi dibenak konsumen. Terdapat setidaknya 5 perusahaan kosmetik yang memasarkan 
Ida Ayu Putu Dian Savitri, Pengaruh Citra Merek, Kualitas Produk...

produknya di Indonesia. Hasil Observasi kisaran harga produk kosmetik yang dilakukan di Kota Denpasar pada bulan Pebruari 2018, diketahui bahwa produk kosmetik merek The Body Shop mempunyai harga yang tinggi yaitu kisarannya antara Rp.200.000 sampai Rp.269.000, sementara Oriflame, Wardah, Mustika Ratu dan Dove mempunyai kisaran harga antara Rp.52.000 sampai Rp.139.000 dan merupakan produk kosmetik yang menyasar segmen konsumen kelas menengah. Tingginya tingkat persaingan diatas maka penting bagi perusahaan untuk menjaga konsumennya, karena konsumen merupakan sumber pendapatan (profit) bagi perusahaan.

Perusahaan yang bergerak dibidang kosmetika yaitu PT. Orindo Alam Ayu atau yang lebih dikenal dengan Oriflame, Awal mula Oriflame didirikan di Stockholm, Swedia pada tahun 1967 oleh dua orang bersaudara Jonas af Jochnick dan Robert af Jochnick sebagai (Oriflame co - founder). Oriflame memiliki berbagai macam produk kecantikan yang inovatif dan terinspirasi dari alam khas Swedia. Produk Oriflame mulai masuk dan dipasarkan di Indonesia sejak tahun 1986 (id.oriflame). Menyasar segmen pasar yang tepat menjadikan Oriflame mampu bertahan di Indonesia. Oriflame dipilih karena produk - produknya mampu bersaing dengan produk kosmetik merek lain dan mampu menempati Top Brand pada produk tertentu.

Perusahaan sangat penting menentukan produk yang tepat tentang apa yang konsumen butuhkan karena akan berpengaruh positif terhadap niat beli ulang pelanggan (Tariq et al., 2013). Niat beli ulang terjadi ketika konsumen melakukan kegiatan pembelian ulang untuk kedua kali atau lebih, dimana alasan pembelian 
ulang terutama dipicu oleh pengalaman pelanggan terhadap produk dan jasa. Niat beli ulang pasti akan tumbuh pada diri konsumen ketika konsumen merasakan kepuasan dan kenyamanan akan produk yang konsumen beli sebelumnya dan ingin menggunakan kembali. Niat membeli ulang adalah kecenderungan perilaku membeli dari konsumen pada suatu produk barang dan jasa yang dilakukan secara berulang dalam jangka waktu tertentu dan didasarkan pada pengalaman yang telah dilakukan dimasa lampau (Suryana dan Dasuki, 2013). Niat beli ulang adalah tahap kecenderungan responden untuk bertindak setelah konsumen merasakan kepuasan (Resti dan Soesanto, 2016).

Kepuasan dapat tercipta saat perusahaan dapat memenuhi kebutuhan konsumen dengan baik (Moraga et al., 2012). Konsumen akan merasa telah membuat keputusan yang tepat saat konsumen merasa puas atas produk yang telah dikonsumsinya (Kautsar et al., 2012). Penelitian oleh Fang (2014) yang menemukan bahwa kepuasan berpengaruh positif dan signifikan terhadap niat beli ulang pada toko online. Penelitian oleh Huang et al. (2014) yang menemukan bahwa kepuasan mempunyai efek positif dan signifikan terhadap niat membeli ulang. Penelitian oleh Resti dan Soesanto (2016) yang menemukan bahwa kepuasan pelanggan berpengaruh positif dan signifikan terhadap niat beli ulang Rumah Kecantikan Sifra di Pati. Kepuasan ini diharapkan akan membawa dampak positif bagi Oriflame, diantaranya saat Oriflame mengeluarkan produk kosmetik baru, timbul keinginan dibenak pelanggan untuk melakukan pembelian ulang terhadap produk kosmetik merek Oriflame dikarenakan konsumen merasa puas akan produk yang dibeli sebelumnya. 
Ida Ayu Putu Dian Savitri, Pengaruh Citra Merek, Kualitas Produk...

Menciptakan kepuasan pelanggan ini dapat dilakukan dengan membangun citra merek yang positif. Citra merek merepresentasikan asosiasi - asosiasi yang diaktifkan dalam memori ketika berpikir mengenai merek tertentu (Shimp, 2014:40). Semakin baik citra merek yang dimiliki suatu produk akan semakin tinggi pula kepuasan pelanggan, dengan menerapkan strategi yang unik, atau menerapkan strategi deferensiasi dalam pemasaran produknya, akan mempermudah melekatkan merek dibenak konsumennya. Penelitian oleh Susanti dan Wardana (2015) menemukan bahwa citra merek berpengaruh positif signifikan terhadap kepuasan pelanggan produk kosmetik hijau merek The Body Shop.

Selain citra merek, dalam menciptakan kepuasan pelanggan ini dapat dilakukan dengan menjual produk yang berkualitas. Kualitas produk adalah kecocokan penggunaan produk untuk memenuhi kebutuhan dan kepuasan pelanggan (Zulian Zamit, 2013:6). Pengalaman konsumen dalam membeli produk akan menghasilkan penilaian konsumen terhadap produk tersebut (Bailia dkk, 2014). Penelitian oleh Anggraeni dkk. (2016) menemukan bahwa kualitas produk berpengaruh positif dan signifikan terhadap kepuasan pelanggan, sehingga semakin baik kualitas yang dimiliki suatu produk akan semakin tinggi pula kepuasan pelangan. Penelitian yang dilakukan oleh Purnamasari (2015) yang menyatakan bahwa kualitas produk sangat berpengaruh signifikan terhadap kepuasan pelanggan terhadap produk M2 Fashion Online. Penelitian oleh Puspasari (2014) menemukan bahwa kualitas produk berpengaruh positif dan signifikan terhadap kepuasan pelanggan. Usaha yang dilakukan Oriflame untuk 
menyakinkan konsumennya jika produk yang dijual adalah produk yang berkualitas yaitu memberitahu kepada konsumennya jika produk yang di produksi adalah produk yang berskala internasional hal tersebut diperkuat dengan produknya di produksi di 5 unit produksi dan memiliki 100 orang ilmuan dan memiliki banyak produk-produk sehingga dapat memperkuat jika Oriflame memiliki kualitas yang baik.

Selain citra merek dan kualitas produk, dalam menciptakan kepuasan pelanggan ini dapat dilakukan dengan membangun persepsi harga yang positif. Harga merupakan salah satu faktor penentu dalam menentukan suatu keputusan pembelian terhadap produk maupun jasa. Kesesuaian harga dan kualitas yang ditawarkan perlu menjadi perhatian demi terciptanya citra yang baik (Beneke dan Zimmerman, 2014). Persepsi harga berpengaruh positif dan signifikan terhadap kepuasan pelanggan (Martha, 2015). Penelitian oleh Haryati dan Venesia (2015) menemukan bahwa persepsi harga berpengaruh signifikan terhadap kepuasaan pelanggan maskapai penerbangan Tiger Air Mandala. Penelitian oleh Sulastri (2017) menemukan bahwa besarnya pengaruh persepsi harga terhadap kepuasan berpengaruh secara signifikan baik berpengaruh langsung maupun tidak langsung. Sehingga semakin baik persepsi harga yang dimiliki suatu produk maka akan semakin tinggi pula kepuasan pelanggan. Dampaknya jika perusahaan Oriflame mempunyai persepsi harga yang positif terhadap produknya adalah tingkat pembelian akan semakin tinggi diakibatkan konsumen mempunyai persepsi yang baik akan harga yang didapatkan dan harga yang didapatkan sesuai dengan 
kualitas yang didapatkan, dampak positifnya konsumen akan selalu setia untuk membeli produk tersebut.

Penelitian mengenai pengaruh citra merek, kualitas produk dan harga produk kosmetik pernah dilakukan oleh Sulistyari (2012). Penelitian oleh Yana dkk. (2015) menemukan bahwa citra merek berpengaruh positif dan signifikan terhadap kepuasan. Penelitian oleh Puspasari (2014) menemukan bahwa kualitas produk berpengaruh positif dan signifikan terhadap kepuasan. Penelitian oleh Darmawan dan Ekawati (2017) menemukan bahwa harga berpengaruh positif dan signifikan terhadap kepuasan. Hasil Penelitian yang berbeda ditemukan dalam penelitian Palma dan Andjarwati (2016), dalam penelitiannya tersebut kualitas produk tidak berpengaruh signifikan terhadap niat beli ulang dan harga berpengaruh negatif terhadap niat beli ulang. Hasil yang negatif juga ditemukan pada penelitian yang dilakukan oleh Denniswara (2016), dalam penelitian tersebut kualitas produk tidak berpengaruh signifikan terhadap intensi membeli ulang dan harga tidak berpengaruh signifikan terhadap intensi membeli ulang. Hasil penelitian lainnya yang dilakukan oleh Prastiwi (2016), dalam penelitiannya tersebut bahwa kepuasan tidak berpengaruh signifikan terhadap niat membeli ulang. Sejumlah penelitian yang disajikan menunjukkan adanya hasil yang tidak konsisten dalam hubungan antara kualitas produk, dan persepsi harga dengan niat beli ulang. Hal ini diduga karena terdapat satu variabel yaitu kepuasan yang berperan penting dalam menentukan niat beli ulang. Penelitian mengenai hubungan kepuasan terhadap niat beli ulang pernah diteliti oleh Kemas (2015). Pada penelitian tersebut ditemukan bahwa kepuasan berpengaruh positif dan 
signifikan terhadap niat beli ulang pada pelanggan Rumah Makan Kayu Bandar Lampung.

Teori yang digunakan dalam penelitian ini adalah teori perilaku konsumen. Menurut teori tersebut keputusan untuk membeli merupakan hasil perhitungan ekonomi rasional yang sadar. Pembeli individual berusaha menggunakan barang barang yang akan memberikan kegunaan (kepuasan) paling banyak, sesuai dengan selera dan harga - harga yang relatif. Kemudian teori ini disempurnakan oleh ahli ahli ekonomi neoklasik, yaitu teori kepuasan marginal (marginal utulity), menurut teori ini konsumen akan berusaha mendapatkan kepuasan maksimal, dan konsumen akan meneruskan pembeliannya terhadap suatu produk untuk jangka waktu yang lama, bila konsumen telah mendapatkan kepuasan dari produk yang sama yang telah dikonsumsinya. (Dharmmesta dan Handoko, 2000).

Keterbaruan dalam penelitian ini adalah kepuasan sebagai variabel mediasi sehingga citra merek, kualitas produk dan persepsi harga dalam mempengaruhi berpengaruh terhadap niat beli ulang. Citra merek, kualitas produk dan persepsi harga diasumsikan memiliki pengaruh positif dan signifikan terhadap kepuasan pelanggan dan kepuasan memediasi citra merek, kualitas produk dan persepsi harga terhadap niat beli ulang. Untuk membuktikan asumsi tersebut, diperlukan penelitian lebih jauh dengan melibatkan variabel tersebut. Oleh karena itu, penelitian tentang fenomena produk kosmetik merek Oriflame ini akan membahas mengenai hubungan variabel citra merek, kualitas produk dan persepsi harga terhadap kepuasan dan pengaruh kepuasan pelanggan terhadap citra merek, kualitas produk dan persepsi harga terhadap niat beli ulang. 
Ida Ayu Putu Dian Savitri, Pengaruh Citra Merek, Kualitas Produk...

Tujuan penelitian ini untuk menganalisis pengaruh pengaruh citra merek, kualitas produk dan persepsi harga terhadap kepuasan dan niat beli ulang. Penelitian ini memiliki dua maanfaat, yaitu manfaat teoritis dan kegunaan praktis. Hasil penelitian ini diharapkan dapat memberikan kontribusi empiris tentang hubungan antara variabel citra merek, kualitas produk dan persepsi harga terhadap kepuasan pelanggan dan niat beli ulang, dan pengembangan ilmu pemasaran. Disamping itu, hasil penelitian ini diharapkan dapat menjadi referensi bagi perusahaan untuk memanfaatkan aspek citra merek, kualitas produk dan persepsi harga, kepuasan pelanggan dan niat beli ulang produk kosmetik merek Oriflame.

Kerangka konseptual yang diajukan sebagai dasar penentu hipotesis ditunjukan pada Gambar 1 sebagai berikut.

Gambar 1. Kerangka Konseptual Penelitian

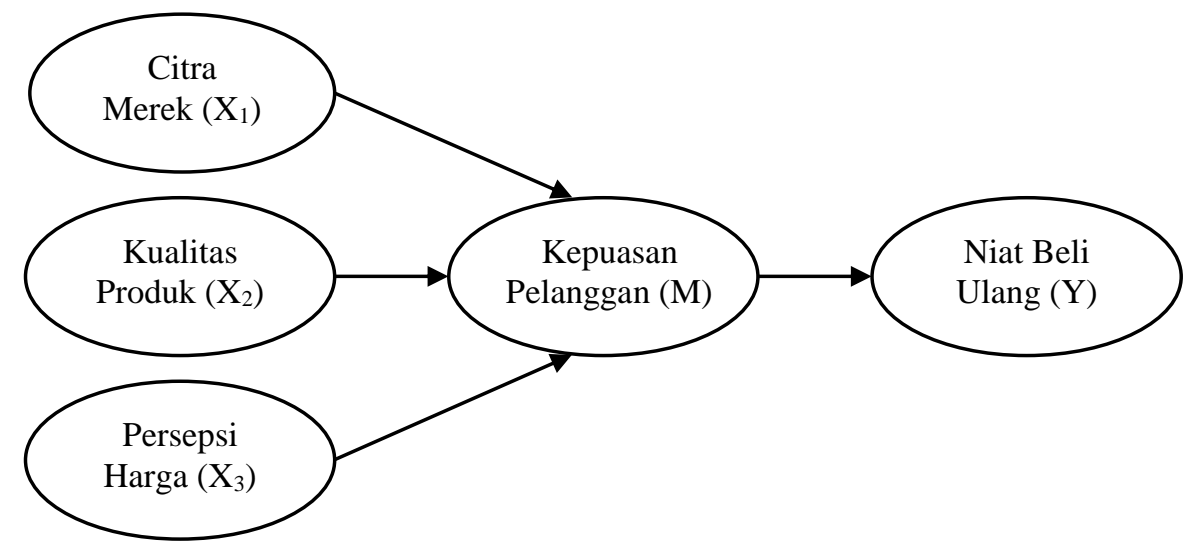

Citra atau image adalah persepsi masyarakat terhadap perusahaan atau produknya (Roring dkk., 2014). Konsumen cenderung menjadikan citra sebagai acuan sebelum melakukan pembelian suatu produk (Lin et al., 2007). Citra merek dapat juga diartikan sebagai asosiasi merek yang muncul didalam benak konsumen dalam jangka waktu yang lama dan bersifat konsisten (Koubaa, 2008). 
Citra merek merupakan representasi dari keseluruhan persepsi terhadap merek dan dibentuk dari informasi dan pengalaman masa lalu terhadap merek itu. Citra merek adalah persepsi dan keyakinan yang dipegang oleh konsumen, seperti tercermin dalam asosiasi yang terjadi dalam memori konsumen (Kotler dan Keller, 2009:403). Citra merek merupakan sub variabel yang kuat dalam perusahaan dan sangat penting dalam keputusan pembelian bagi pelanggan (Nigam et al., 2011). Rekomendasi citra merek yang dimiliki konsumen akan membantu konsumen dalam mengambil keputusan pembelian (Arslan, 2014).

Penelitian oleh Nila (2012) menemukan bahwa citra merek berpengaruh secara signifikan terhadap kepuasan konsumen kamera Canon DSLR, dan menyatakan bahwa konsumen merasa puas dengan citra merek yang berarti perusahaan harus mampu serta berupaya untuk meningkatkan bagaimana manfaat produk, kemudahan memperoleh produk, merek yang mudah dikenali dan sesuai dengan kebutuhan konsumen, yang nantinya menjadikan konsumen lebih puas dan mengabaikan penawaran produk lain atau loyal terhadap produk yang digunakan. Penelitian oleh Kurniawati dkk. (2014) menemukan bahwa citra merek berpengaruh signifikan terhadap kepuasan. Manfaat yang diberikan oleh suatu merek dapat memuaskan kebutuhan dan keinginan konsumen. Penelitian oleh Pusparani dan Rastini (2014) menemukan bahwa kepuasan konsumen dibentuk oleh merek mempunyai citra positif, merek memiliki ciri khas dan merek produk yang dikenal luas, Semakin baik citra merek dibenak konsumen maka konsumen akan merasa puas dalam menggunakan produk tersebut. Penelitian oleh Susanti dan Wardana (2015) menemukan bahwa citra merek berpengaruh positif 
Ida Ayu Putu Dian Savitri, Pengaruh Citra Merek, Kualitas Produk...

signifikan terhadap kepuasan pelanggan produk kosmetik hijau merek The Body Shop. Hal tersebut berarti semakin citra merek yang dipersepsikan positif oleh pelanggan, mampu meningkatkan kepuasan yang dirasakan oleh pelanggan tersebut. Penelitian oleh Sulistiyanto (2015) menemukan bahwa citra merek berpengaruh positif dan signifikan terhadap kepuasan pelanggan Apotik Dela di Semarang, sehingga semakin baik citra merek maka kepuasan pelanggan juga akan semakin meningkat. Berdasarkan hasil empiris pada penelitian diatas, hipotesis yang dapat diajukan dalam penelitian ini.

$\mathrm{H}_{1}$ : Citra merek berpengaruh positif dan signifikan terhadap kepuasan pelanggan.

Penelitian oleh Mulyono dkk. (2007) menemukan bahwa kualitas produk sebagai variabel bebas memiliki pengaruh positif yang signifikan terhadap kepuasan konsumen sebagai variabel dependen, sehingga semakin tinggi kualitas produk maka semakin tinggi kepuasan konsumen. Penelitian oleh Maria dan Ansori (2013) menemukan bahwa kualitas produk berpengaruh positif dan signifikan terhadap kepuasan konsumen King Cake. Hal ini berarti semakin baik kualitas produk yang diberikan oleh King Cake, maka semakin merasa puas terhadap produk King Cake. Penelitian oleh Bailia dkk. (2014) menemukan bahwa kualitas produk secara parsial berpengaruh positif terhadap kepuasan, Pengalaman konsumen dalam membeli produk akan menghasilkan penilaian konsumen terhadap produk tersebut. Penelitian oleh Puspasari (2014) menemukan bahwa kualitas produk berpengaruh positif dan signifikan terhadap kepuasan pelanggan. Semakin tinggi kualitas produk yang dirasakan semakin tinggi tingkat kepuasan pelanggan migrasi listrik prabayar dikelurahan Menganti. Penelitian 
yang dilakukan oleh Purnamasari (2015) yang menyatakan bahwa kualitas produk sangat berpengaruh signifikan terhadap kepuasan pelanggan terhadap produk M2 Fashion Online. Berdasarkan hasil empiris pada penelitian diatas, hipotesis yang dapat diajukan dalam penelitian ini.

$\mathrm{H}_{2}$ : Kualitas produk memiliki pengaruh positif dan signifikan terhadap kepuasan pelanggan.

Penelitian oleh Montung dkk. (2015) menemukan bahwa persepsi harga mempunyai pengaruh yang signifikan positif secara parsial terhadap kepuasan pelanggan. Persepsi harga di Restoran Kawan Baru Manado telah dilaksanakan dengan baik sehingga harga dipersepsikan positif oleh pelanggannya. Penelitian oleh Haryati dan Venesia (2015) menemukan bahwa persepsi harga berpengaruh signifikan terhadap kepuasaan pelanggan maskapai penerbangan Tiger Air Mandala. Penelitian oleh Sulastri (2017) menemukan bahwa besarnya pengaruh persepsi harga terhadap kepuasan berpengaruh secara signifikan baik berpengaruh langsung maupun tidak langsung. Kewajaran tingkat harga yang ditawarkan kepada pelanggan perlu diperhatikan oleh perusahaan demi meningkatkan kepuasan pelanggan. Penelitian oleh Darmawan dan Ekawati (2017) menemukan bahwa harga berpengaruh positif dan signifikan terhadap kepuasan. Kepuasan tersendiri yang dirasakan konsumen karena produk yang dikonsumsi sesuai dengan harga yang diberikan. Berdasarkan hasil empiris pada penelitian diatas, hipotesis yang dapat diajukan dalam penelitian ini.

$\mathrm{H}_{3}$ : Persepsi harga memiliki pengaruh positif dan signifikan terhadap kepuasan pelanggan. 
Ida Ayu Putu Dian Savitri, Pengaruh Citra Merek, Kualitas Produk...

Menurut penelitian yang dilakukan oleh Kemas M.Reza (2015) yang menyatakan bahwa kepuasan konsumen berpengaruh positif terhadap niat beli ulang pada Rumah Makan Kayu Bandar Lampung. Penelitian oleh Fang (2014) yang menemukan bahwa kepuasan berpengaruh positif dan signifikan terhadap niat beli ulang pada toko online. Penelitian oleh Huang et al. (2014) yang menemukan bahwa kepuasan mempunyai efek positif dan signifikan terhadap niat membeli ulang. Fang et al. (2011) dalam penelitiannya menjelaskan bahwa niat membeli ulang paling dominan dipengaruhi oleh kepuasan. Penelitian oleh Penelitian oleh Resti dan Soesanto (2016) yang menemukan bahwa kepuasan pelanggan berpengaruh positif dan signifikan terhadap niat beli ulang Rumah Kecantikan Sifra di Pati. Berdasarkan hasil empiris pada penelitian diatas, hipotesis yang dapat diajukan dalam penelitian ini.

$\mathrm{H}_{4}$ : Kepuasan pelanggan memiliki pengaruh positif dan signifikan terhadap niat beli ulang.

Penelitian oleh Adiputra Febrian dan Sutopo (2016) yang menyatakan bahwa kepuasan memediasi persepsi harga dan niat beli ulang Holycow Semarang. Penelitian oleh Suandana, Rahyuda dan Kerti Yasa (2016) yang menyatakan bahwa kepuasan pelanggan terbukti signidikan dan cukup memediasi pengalaman membeli secara online terhadap minat membeli kembali. Hasil yang berbeda ditemukan oleh Penelitian Wijaya dan Nurcaya (2017) yang menyatakan bahwa kepuasan pelanggan berpengaruh tidak langsung dan tidak mampu sebagai mediator pengaruh kualitas produk dan harga terhadap loyalitas.

$\mathrm{H}_{5}$ : Kepuasan pelanggan mampu memediasi secara signifikan citra merek, kualitas produk dan persepsi harga terhadap niat beli ulang. 


\section{METODE PENELITIAN}

Penelitian ini dilakukan di Kota Denpasar. Mobilitas yang tinggi di Kota Denpasar mengakibatkan kebutuhan akan produk kosmetika sebagai penunjang penampilan menjadi tinggi dan Kantor cabang Oriflame yang berada di Bali berpusat di Kota Denpasar. Objek yang digunakan adalah perilaku konsumen, khususnya perilaku penggunaan dan pembelian produk kosmetik merek Oriflame. Niat beli ulang pada produk ditentukan oleh variabel citra merek, kualitas produk, persepsi harga dan kepuasan pelanggan yang membeli produk kosmetik merek Oriflame.

Citra merek didefinisikan sebagai seperangkat keyakinan ide dan kesan yang dimiliki konsumen terhadap produk kosmetik merek Oriflame. Mengacu pada penelitian Adil (2012), Kurniawati dkk. (2014) dan Sulistiyanto (2015) dan setelah dimodifikasi dengan tempat penelitian, maka indikator yang dapat digunakan sebagai berikut: 1). Aspek favorable dapat dinilai dari produk kosmetik merek Oriflame adalah produk yang mudah diingat dibenak konsumen. 2). Kompetisi berkaitan dengan kinerja produk kosmetik merek Oriflame mampu bersaing dengan produk kosmetika merek lain. 3). Manfaat pengalaman dapat dinilai dari produk kosmetik merek Oriflame yang berkaitan dengan pengalaman konsumen saat menggunakan produk Oriflame.

Kualitas produk adalah segala sesuatu yang dimiliki produk kosmetik merek Oriflame yang dapat ditawarkan kepasar untuk mendapatkan perhatian, dibeli, digunakan oleh konsumen. Mengacu pada penelitian Bailia dkk (2014), Puspasari (2014) dan Purnamasari (2015) dan setelah dimodifikasi dengan tempat 
Ida Ayu Putu Dian Savitri, Pengaruh Citra Merek, Kualitas Produk...

penelitian, maka indikator yang dapat digunakan sebagai berikut: 1). Daya Tahan diukur dari umur seberapa ketahanan dari produk kosmetik merek Oriflame. 2). Kualitas yang dipersepsikan seperti merek, iklan, reputasi perusahaan dan negara asal produk kosmetik merek Oriflame, dimensi ini merupakan hal yang penting bagi konsumen yang kurang tau informasi lengkap tentang produk tersebut. 3). Keistimewaan berkaitan dengan keunggulan yang dimiliki produk kosmetik merek Oriflame adalah produknya dibuat dari bahan bahan yang bagus dan tidak mengandung zat kimia sehingga dapat setara dengan produk kosmetik lain pesaingnya.

Persepsi harga adalah bagaimana informasi harga yang ditawarkan dipahami seluruhnya oleh konsumen produk kosmetik merek Oriflame. Mengacu pada penelitian Beneke dan Zimmerman (2014), Sulastri (2017), Darmawan dan Ekawati (2017) dan setelah dimodifikasi dengan tempat penelitian, maka indikator yang dapat digunakan sebagai berikut: 1). Attractiveness dapat berupa harga yang di tawarkan oleh produk kosmetik merek Oriflame yang dapat menarik minat konsumen sehingga tertarik untuk membeli. 2). Tingkat harga yang relatif yaitu penawaran harga produk yang ditawarkan oleh produk kosmetik merek Oriflame adalah harga yang terbaik dan relatif dengan kualitas yang bagus bila dibandingkan dengan produk kosmetika lainnya. 3). Fairness adalah dapat berupa harga yang ditawarkan oleh produk kosmetik merek Oriflame merupakan harga yang wajar yang tidak terlalu tinggi dan rendah dibandingkan tawaran harga yang ditawarkan produk kosmetik pesaing lainnya. 
Kepuasan adalah ungkapan perasaan senang atau kecewa pelanggan yang muncul saat menggunakan produk kosmetik merek Oriflame. Mengacu pada penelitian Moraga et al. (2012), Ruswanti (2011), dan Huang et al. (2014) dan setelah dimodifikasi dengan tempat penelitian, maka indikator yang dapat digunakan sebagai berikut: 1). Kualitas dan kuantitas produk yang diciptakan oleh produk kosmetik merek Oriflame mampu memenuhi harapan dari konsumennya. 2). Kepuasan yang timbul saat konsumen sedang menggunakan dan mendapat hasil yang baik pada produk kosmetik merek Oriflame. 3). Konsumen telah merasa membuat keputusan yang tepat untuk menggunakan produk kosmetik merek Oriflame.

Niat beli ulang adalah pembelian ulang yang menunjukan keinginan pelanggan untuk melakukan pembelian ulang pada produk kosmetik merek Oriflame. Mengacu pada penelitian Margareta (2008), Suryana dan Dasuki (2013), dan Tariq et al. (2013) dan setelah dimodifikasi dengan tempat penelitian, maka indikator yang dapat digunakan sebagai berikut: 1). Niat konsumen yang berkeinginan selalu membeli ulang produk kosmetik merek Oriflame. 2). Niat konsumen yang cenderung mereferensikan produk kosmetik merek Oriflame yang sudah dibelinya agar dibeli juga oleh orang lain. 3). Niat konsumen yang selalu memiliki preferensi utama pada produk kosmetik merek Oriflame. 4). Niat konsumen yang selalu mencari informasi tentang produk - produk kosmetik merek Oriflame yang diminatinya.

Populasi dari penelitian ini adalah konsumen yang menggunakan produk kosmetik merek Oriflame di Kota Denpasar yang tidak diketahui jumlah pastinya. 
Ida Ayu Putu Dian Savitri, Pengaruh Citra Merek, Kualitas Produk...

Penelitian ini dianalisis dengan multivariate, maka jumlah anggota sampel minimal 5 sampai 10 kali dari jumlah indikator yang diteliti (Malhotra, 2006: 291). Indikator yang digunakan dalam penelitian ini berjumlah 16 indikator sehingga jika menggunakan formula maka ukuran sampel berada pada rentang 80160. Maka dalam penelitian ini banyaknya sampel yang akan digunakan dalah 120 sampel. Sampel ditentukan dengan metode nonprobality sampling dengan metode purposive sampling. Data yang dikumpulkan menggunakan instrumen penelitian berupa kuesioner.

Penelitian ini menggunakan uji instrumen terlebih dahulu. Analisis jalur merupakan teknik model analisis yang digunakan untuk menganalisis pola hubungan antar variabel dengan tujuan untuk mengetahui pengaruh langsung maupun tidak langsung seperangkat variabel bebas terhadap variabel terikat (Riduwan dan Kuncoro, 2008: 2). Masing - masing hipotesis memiliki persamaan struktural yang berbeda, persamaan struktural 1 untuk hipotesis 1, 2 dan 3 adalah sebagai berikut:

$$
\mathrm{M}=\beta_{1} \mathrm{X}_{1}+\beta_{2} \mathrm{X}_{2}+\beta_{3} \mathrm{X}_{3}+\mathrm{e}_{1}
$$

Sedangkan peramaan struktural 2 untuk hipotesis 4 adalah sebagai berikut:

$$
\mathrm{Y}=\beta_{4} \quad \mathrm{M}+\mathrm{e}_{2}
$$

Keterangan:

$\mathrm{Y}=$ Niat beli ulang

$\mathrm{X}_{1}=$ Citra merek

$\mathrm{X}_{2}=$ Kualitas produk

$\mathrm{X}_{3}=$ Persepsi harga

$\mathrm{M}=$ Kepuasan pelanggan

$\mathrm{b}=$ Koefisien garis regresi

$\mathrm{e}=$ error 


\section{PEMBAHASAN}

Oriflame merupakan perusahaan yang bergerak dibidang kosmetika yang awal mula didirikan di Stockholm, Swedia pada tahun 1967 oleh dua orang bersaudara Jonas af Jochnick dan Robert af Jochnick sebagai (Oriflame co founder). Dua saudara itu bermimpi ingin memberi banyak orang kesempatan unttuk memperoleh manfaat dari perawatan kulit yang baik dan kosmetika berkualitas tinggi yang terinspirasi oleh keindahan alam khas Swedia. Produk Oriflame terdiri dari aneka kosmetik, perawatan badan, rambut, wajah dan wewangian yang hanya menggunakan bahan - bahan alami. Oriflame adalah perusahaan kosmetika yang menawarkan produk kosmetik dan perawatan kulit alami berkualitas tinggi melalui jaringan penjual mandiri (independent sales force) yang berbeda dengan sistem retail pada umumnya, sistem penjualan pribadi yang memungkinkan pelanggan untuk memperoleh nasehat dan inspirasi dari orang yang mereka kenal dan percaya.

Produk Oriflame sebagian besar merupakan produk buatan Swedia yang terdiri dari aneka perlengkapan kosmetik dan perawatan tubuh. Keunggulan produk kosmetik Oriflame antara lain: Harga yang terjangkau untuk produk berkualitas tinggi. Produk Oriflame dijamin murni dan berkualitas tinggi serta dikembangkan di pabrik yang berteknologi tinggi dibawah pengawasan mutu dan lingkungan yang ketat. Produk Oriflame tidak diuji cobakan pada hewan, tetapi pada manusia (sukarelawan) dengan menjamin keamanan, kecocokan serta efektifitas produk termasuk untuk kulit sensitif. Tidak menggunakan bahan bahan dari hewani kecuali beeswax dan lanolin. Oriflame menekankan 
Ida Ayu Putu Dian Savitri, Pengaruh Citra Merek, Kualitas Produk...

penggunaan bahan dari sari pati alami sehingga produk aman dan berkualitas tinggi.

Pertama dilakukan uji instrumen yakni uji validitas bertujuan untuk menilai instrumen yang digunakan telah tepat untuk mengukur indikator dalam penelitian. Hasil pengukuran validitas masing - masing instrumen pada variabel disajikan dalam Tabel 2 sebagai berikut.

Tabel 2.

Hasil Uji Validitas

\begin{tabular}{lllll}
\hline No & Variabel & Indikator & $\begin{array}{l}\text { Koefisien } \\
\text { Korelasi }\end{array}$ & Keterangan \\
\hline & & Favorable & 0,678 & Valid \\
1. & \multirow{2}{*}{ Citra Merek } & Kompetisi & 0,690 & Valid \\
& & Manfaat pengalaman & 0,699 & Valid \\
2. & Kualitas Produk & Daya tahan & 0,588 & Valid \\
& & Kualitas yang dipersepsikan & 0,696 & Valid \\
& & Keistimewaan & 0,666 & Valid \\
3. & Persepsi Harga & Attractiveness & 0,693 & Valid \\
& & Tingkat harga yang relatif & 0,560 & Valid \\
& Kepuasan Pelanggan & 0,638 & Valid \\
4. & & Faines & 0,605 & Valid \\
& & Konfirmasi harapan & 0,490 & Valid \\
& & Kepuasan secara keseluruhan & 0,545 & Valid \\
5. & Niat Beli Ulang & Keputusan tepat & 0,437 & Valid \\
& & Niat transaksional & 0,428 & Valid \\
& & Niat referensial & 0,465 & Valid \\
& & Niar preferensial & 0,579 & Valid \\
\hline
\end{tabular}

Sumber: Data diolah, 2018

Hasil uji validitas instrumen penelitian disajikan pada Tabel 2 yang menunjukkan bahwa seluruh indikator dalam variabel citra merek, kualitas produk, persepsi harga, kepuasan pelanggan, dan niat beli ulang memiliki nilai Pearson Correlation yang lebih besar dari angka 0,30 sehingga seluruh indikator tersebut dikatakan telah memenuhi syarat validitas data.

Uji Reliabilitas bertujuan untuk mengukur konsistensi alat ukur yang digunakan. Hasil pengukuran reliabilitas masing-masing variabel disajikan dalam Tabel 3 sebagai berikut. 
Tabel 3.

Hasil Uji Reabilitas

\begin{tabular}{llll}
\hline No. & Variabel & Cronbach's Alpha & Keterangan \\
\hline 1. & Citra Merek & 0,716 & Reliabel \\
2. & Kualitas Produk & 0,674 & Reliabel \\
3. & Persepsi Harga & 0,644 & Reliabel \\
4. & Kepuasan Pelanggan & 0,620 & Reliabel \\
5. & Niat Beli Ulang & 0,635 & Reliabel \\
\hline
\end{tabular}

Sumber: Data diolah, 2018

Hasil uji reliabilitas instrumen pada penelitian ini disajikan pada Tabel 3 yang menunjukkan bahwa kelima instrumen penelitian yaitu citra merek, kualitas produk, persepsi harga, kepuasan pelanggan, dan niat beli ulang memiliki koefisien cronbach's alpha yang lebih besar dari angka 0,60 sehingga pernyataan pada kuesioner dapat dikatakan reliabel dan indikator yang digunakan merupakan indikator yang konsisten.

Perhitungan koefisien jalur dilakukan dengan menggunakan SPSS 13, hasil dari pengolahan data untuk persamaan regresi 1 disajikan dalam Tabel 4 sebagai berikut.

\section{Tabel 4.}

Hasil Analisis Jalur Persamaan Regresi 1

\begin{tabular}{|c|c|c|c|c|c|}
\hline \multirow[t]{2}{*}{ Model } & \multicolumn{2}{|c|}{ Unstandardized Coefficients } & \multirow{2}{*}{$\begin{array}{c}\begin{array}{c}\text { Standardized } \\
\text { Coefficients }\end{array} \\
\text { Beta } \\
\end{array}$} & \multirow[t]{2}{*}{$\mathbf{t}$} & \multirow[t]{2}{*}{ Sig. } \\
\hline & $\mathbf{B}$ & Std. Error & & & \\
\hline 1.(Constant) & 7,389 & 1,392 & & 5,309 & 0,000 \\
\hline Citra merek & 0,373 & 0,074 & 0,415 & 3,352 & 0,017 \\
\hline Kualitas produk & 0,234 & 0,079 & 0,356 & 2,694 & 0,026 \\
\hline Persepsi harga & 0,305 & 0,078 & 0,319 & 2,343 & 0,022 \\
\hline $\mathrm{R}$ & 0,372 & & & & \\
\hline $\mathrm{R}_{1}^{2}$ & 0,518 & & & & \\
\hline Adjusted $\mathrm{R}^{2}$ & 0,465 & & & & \\
\hline F hitung & 12,324 & & & & \\
\hline Sig. F & 0,002 & & & & \\
\hline
\end{tabular}

Berdasarkan data yang disajikan pada Tabel 4, maka persamaan striktural untuk hipotesis 1, 2 dan 3 dapat disusun sebagai berikut :

$$
\mathrm{M}=0,415 \mathrm{X}_{1}+0,356 \mathrm{X}_{2}+0,319 \mathrm{X}_{3}+\mathrm{e}_{1}
$$


Ida Ayu Putu Dian Savitri, Pengaruh Citra Merek, Kualitas Produk...

Hasil pengolahan data untuk persamaan regresi 2 disajikan dalam Tabel 5 sebagai berikut.

Tabel 5.

Hasil Analisis Jalur Persamaan Regresi 2

\begin{tabular}{|c|c|c|c|c|c|}
\hline \multirow[t]{2}{*}{ Model } & \multicolumn{2}{|c|}{$\begin{array}{l}\text { Unstandardized } \\
\text { Coefficients }\end{array}$} & \multirow{2}{*}{$\begin{array}{c}\begin{array}{c}\text { Standardized } \\
\text { Coefficients }\end{array} \\
\text { Beta } \\
\end{array}$} & \multirow[t]{2}{*}{$\mathbf{t}$} & \multirow[t]{2}{*}{ Sig. } \\
\hline & B & Std. Error & & & \\
\hline 1. (Constant) & 15,474 & 1,420 & & 10,894 & 0,000 \\
\hline Kepuasan & 0,321 & 0,112 & 0,399 & 2,078 & 0,013 \\
\hline $\mathrm{R}$ & 0,430 & & & & \\
\hline $\mathrm{R}_{2}^{2}$ & 0,411 & & & & \\
\hline Adjusted $\mathrm{R}^{2}$ & 0,332 & & & & \\
\hline $\mathrm{F}$ hitung & 8,139 & & & & \\
\hline Sig. F & 0,003 & & & & \\
\hline
\end{tabular}

Berdasarkan data yang disajikan pada Tabel 5, maka persamaan struktural untuk hipotesis 4 dapat disusun sebagai berikut:

$$
\begin{array}{ll}
\mathrm{Y} & =\beta_{4} \mathrm{M}+\mathrm{e}_{1} \\
\mathrm{Y} & =0,399 \mathrm{X}_{1}+\mathrm{e}_{2}
\end{array}
$$

Berdasarkan persamaan regresi 1 dan persamaan regresi 2, diketahui nilai $\mathrm{R}_{1}^{2}=0,418$ dan $\mathrm{R}_{2}^{2}=0,311$, maka nilai eror untuk masing-masing persamaan adalah sebagai berikut:

$$
\begin{array}{ll}
\mathrm{e} & =\sqrt{1-\mathrm{Ri}^{2}} \ldots \ldots \ldots \ldots \ldots \ldots \ldots \ldots \ldots \ldots \ldots \ldots \ldots \\
\mathrm{e}_{1} & =\sqrt{1-\mathrm{R}_{1}^{2}}=\sqrt{1-0,518^{2}}=0,855 \\
\mathrm{e}_{2} & =\sqrt{1-\mathrm{R}_{2}^{2}}=\sqrt{1-0,411^{2}}=0,911
\end{array}
$$

Berdasarkan perhitungan nilai standar eror, didapatkan hasil $\mathrm{e}_{1}$ sebesar 0,855 dan $\mathrm{e}_{2}$ sebesar 0,911. Dari nilai $\mathrm{e}_{1}$ dan $\mathrm{e}_{2}$ yang telah diketahui maka hasil koefisien determinasi total dihitung sebagai berikut :

$$
\mathrm{R}^{2} \mathrm{~m}=1-\left(\mathrm{Pe}_{1}\right)^{2}\left(\mathrm{Pe}_{2}\right)^{2}
$$




$$
\begin{aligned}
& =1-(0,855)^{2}(0,911)^{2} \\
& =0,393
\end{aligned}
$$

Koefisien determinasi total sebesar 0,393, artinya bahwa sebesar 39,3\% variasi variabel niat beli ulang dipengaruhi oleh variasi citra merek, kualitas produk, persepsi harga, dan kepuasan pelanggan, sedangkan sisanya sebesar $60,7 \%$ dijelaskan oleh faktor lain yang tidak dimasukkan ke dalam model. Hasil pada Tabel 4 dan 5 menunjukkan nilai koefisien sig. $\mathrm{F}$ adalah 0,002 dan 0,003. Nilai koefisien ini lebih kecil dari 0,05 sehingga dapat disimpulkan bahwa model persamaan struktural 1 dan 2 telah memenuhi syarat Goodness of Fit melalui uji F.

Uji sobel dilakukan dengan cara menguji kekuatan pengaruh tidak langsung variabel bebas (X) ke variabel terikat (Y) melalui variabel mediasi (M). Menguji signifikansi pengaruh tidak langsung kepuasan dengan citra merek, kualitas produk dan persepsi harga terhadap niat beli ulang. Berdasarkan perhitungan diperoleh nilai t hitung sebesar 2,974. Nilai t hitung sebesar 2,974 lebih besar dari 1,96. Jika nilai kalkulasi t hitung lebih besar dari t tabel sebesar 1,96 maka variabel mediator kepuasan pelanggan termasuk ke dalam mediasi parsial karena dinilai secara signifikan memediasi hubungan antara citra merek terhadap niat beli ulang.

Berdasarkan perhitungan diperoleh nilai t hitung sebesar 2,754. Nilai t hitung sebesar 2,754 lebih besar dari 1,96. Jika nilai kalkulasi t hitung lebih besar dari t tabel sebesar 1,96 maka variabel mediator kepuasan pelanggan termasuk ke dalam mediasi parsial karena dinilai secara signifikan memediasi hubungan antara 
kualitas produk terhadap niat beli ulang. Perhitungan diperoleh nilai t hitung sebesar 2,642. Nilai t hitung sebesar 2,642 lebih besar dari 1,96. Jika nilai kalkulasi t hitung lebih besar dari t tabel sebesar 1,96 maka variabel mediator kepuasan pelanggan termasuk ke dalam mediasi parsial karena dinilai secara signifikan memediasi hubungan antara persepsi harga terhadap niat beli ulang.

Pengujian hipotesis terhadap hubungan kedua variabel ini menunjukan hasil yang diterima, yaitu citra merek berpengaruh positif dan signifikan terhadap kepuasan pelanggan. Itu berarti, semakin baik citra merek produk kosmetik merek Oriflame, maka akan semakin tinggi kepuasan pelanggan terhadap produk tersebut.

Hasil rangkuman penilaian responden yang disajikan dalam deskripsi variabel penelitian menunjukan bahwa penilaian responden terhadap citra merek berada dalam kategori sangat baik sehingga menghasilkan tingkat kepuasan berada dalam kategori sangat baik. Responden merasa puas dengan favorabel yang dimiliki oleh produk kosmetik merek Oriflame yaitu produknya mudah diingat dibenak konsumennya. Strategi Oriflame menanamkan citra merek yang baik berhasil meningkatkan kepuasan pelanggan produknya.

Hasil penelitian ini mendukung temuan sejumlah penelitian terdahulu seperti Nila (2012), Kurniawati dkk. (2014), Pusparani dan Rastini (2014), Susanti dan Wardana (2015), Sulistiyanto (2015) yang menunjukan bahwa citra merek berpengaruh positif dan signifikan terhadap kepuasan pelanggan.

Pengujian hipotesis terhadap hubungan yaitu kualitas produk berpengaruh positif dan signifikan terhadap kepuasan pelanggan. Itu berarti, semakin baik 
kualitas produk kosmetik merek Oriflame, maka akan semakin tinggi kepuasan pelanggan terhadap produk tersebut.

Hasil rangkuman penelitian responden yang disajikan dalam deskripsi variabel penelitian menunjukan bahwa penelitian responden terhadap kualitas produk berada dalam kategori sangat baik sehingga menghasilkan tingkat kepuasan berada dalam kategori sangat baik. Responden merasa puas dengan daya tahan dan keistimewaan yang diberikan produk kosmetik merek Oriflame. Strategi Oriflame yang mempunyai daya tahan pada setiap produknya dan selalu memberikan keistimewaan dengan selalu menciptakan produk - produk dengan bahan yang alami dan berkualitas, hal tersebut berhasil meningkatkan kepuasan pelanggan terhadap produknya.

Hasil penelitian ini mendukung temuan sejumlah penelitian terdahulu seperti Maria dan Ansori (2013), Bailia dkk. (2014), Puspasari (2014), Purnamasari (2015), Anggraeni (2016) yang menunjukan bahwa kualitas produk berpengaruh positif dan signifikan terhadap kepuasan pelanggan.

Pengujian hipotesis terhadap persepsi harga berpengaruh positif dan signifikan terhadap kepuasan pelanggan. Itu berarti, semakin baik persepsi harga yang dimiliki produk kosmetik merek Oriflame, maka akan semakin tinggi kepuasan pelanggan.

Hasil rangkuman penilaian responden yang disajikan dalam deskripsi variabel penelitian menunjukan bahwa penilaian responden terhadap persepsi harga berada dalam kategori sangat baik. Responden merasa puas dengan tingkat harga yang relatif yang dimiliki produk kosmetik merek Oriflame. Strategi 
Ida Ayu Putu Dian Savitri, Pengaruh Citra Merek, Kualitas Produk...

Oriflame dalam menawarkan harga yang terjangkau bagi konsumennya. Menawarkan harga produk yang bersaing dengan tetap menjaga kualitas baik mampu meningkatkan kepuasan pelanggan. Konsumen merasa puas terhadap kesesuaian manfaat yang dirasakan dengan harga yang dibayarkan saat membeli produk kosmetik merek Oriflame.

Hasil penelitian ini mendukung temuan sejumlah penelitian terdahulu seperti Montung dkk. (2015), Haryati dan Venesia (2015), Sulastri (2017), Darmawan dan Ekawati (2017) yang menunjukan bahwa persepsi harga memiliki pengaruh positif dan signifikan terhadap kepuasan pelanggan. Pengujian hipotesis terhadap hubungan kepuasan pelanggan berpengaruh positif dan signifikan terhadap niat beli ulang. Itu berarti, semakin baik kepuasan yang dirasakan pelanggan produk kosmetik merek Oriflame, maka akan semakin tinggi pula niat beli ulang pada produk tersebut.

Hasil rangkuman penilaian responden yang disajikan dalam deskripsi variabel penelitian menunjukan bahwa kepuasan pelanggan berada dalam kategori sangat baik. Responden akan berniat untuk membeli ulang karena merasa puas dengan produk kosmetik merek Oriflame. Citra merek, kualitas produk dan persepsi harga produk kosmetik merek Oriflame mampu meningkatkan kepuasan pelanggan. Kepuasan ini berdampak secara positif dan signifikan terhadap niat beli ulang produk kosmetik merek Oriflame. Strategi Oriflame dalam meningkatkan kepuasan pelanggannya dengan menghadirkan citra merek yang baik, kualitas produk yang baik dan persepsi harga yang baik dan akan mampu menciptakan niat beli ulang produknya. Pelanggan yang puas akan berniat untuk 
membeli ulang lagi produk kosmetik merek Oriflame dan akan merekomendasikan kepada orang lain. Rekomendasi ini akan membantu perusahaan dalam mendatangkan dan memperoleh konsumen baru.

Hasil penelitian ini mendukung temuan sejumlah penelitian terdahulu seperti Fang et al. (2011), Huang et al. (2014), Fang (2014), Kemas M.Reza (2015), Resti dan Soesanto (2016) yang menunjukan kepuasan pelanggan berpengaruh positif dan signifikan terhadap niat beli ulang. Hasil pada analisis jalur pada Tabel 4.9 dapat diketahui variabel citra merek merupakan variabel yang paling berpengaruh terhadap kepuasan pelanggan. Citra produk kosmetik merek Oriflame sebagai produk kosmetik yang berkompeten memiliki pengaruh paling besar dalam meningkatkan kepuasan pelanggan. Diposisi kedua, variabel kualitas produk merupakan variabel yang dapat mempengaruhi kepuasan pelanggan, daya tahan produk kosmetik merek Oriflame yang dirasakan dapat mempengaruhi kepuasan pelanggan. Diposisi terakhir, adalah variabel persepsi harga yang berpengaruh terhadap kepuasan pelanggan. Penawaran harga yang terjangkau dan menarik dengan kualitas produk yang bagus mampu menciptakan kepuasan pelanggan. Ketiga variabel ini dapat menciptakan kepuasan pelanggan produk kosmetik merek Oriflame, dampak lebih jauhnya kepuasan ini telah menciptakan niat beli ulang. Pelanggan yang berniat membeli ulang timbul karena kepuasan yang dirasakan, dan akan merekomendasikan produk kosmetik merek Oriflame kepada orang lain.

Pengujian hipotesis terhadap hubungan kepuasan mampu memediasi citra merek, kualitas produk dan persepsi harga terhadap niat beli ulang. Berdasarkan 
perhitungan diperoleh nilai t hitung sebesar 2,974. Nilai t hitung sebesar 2,974 lebih besar dari 1,96. Jika nilai kalkulasi t hitung lebih besar dari t tabel sebesar 1,96 maka variabel mediator kepuasan pelanggan termasuk ke dalam mediasi parsial karena dinilai secara signifikan memediasi hubungan antara citra merek terhadap niat beli ulang. Sedangkan kepuasan memediasi kualitas produk terhadap niat beli ulang Berdasarkan perhitungan diperoleh nilai t hitung sebesar 2,754. Nilai thitung sebesar 2,754 lebih besar dari 1,96. Jika nilai kalkulasi t hitung lebih besar dari t tabel sebesar 1,96 maka variabel mediator kepuasan pelanggan termasuk ke dalam mediasi parsial karena dinilai secara signifikan memediasi hubungan antara kualitas produk terhadap niat beli ulang, dan berdasarkan dilihat secara signifikan memediasi hubungan antara persepsi harga terhadap niat beli ulang Berdasarkan perhitungan diperoleh nilai t hitung sebesar 2,642. Nilai t hitung sebesar 2,642 lebih besar dari 1,96. Jika nilai kalkulasi t hitung lebih besar dari t tabel sebesar 1,96 maka variabel mediator kepuasan pelanggan termasuk ke dalam mediasi parsial karena dinilai secara signifikan memediasi hubungan antara persepsi harga terhadap niat beli ulang.

\section{SIMPULAN DAN SARAN}

Berdasarkan hasil pembahasan, dapat ditarik simpulan diantaranyta sebagai berikut: 1). Citra merek berpengaruh positif dan signifikan terhadap kepuasan pelanggan, sehingga semakin baik citra merek yang dimiliki produk kosmetik merek Oriflame, maka akan semakin tinggi pula kepuasan pelanggan. 2). Kualitas produk berpengaruh positif dan signifikan terhadap kepuasan pelanggan, sehingga semakin baik kualitas produk yang dimiliki produk kosmetik 
merek Oriflame, maka akan semakin tinggi pula kepuasan pelanggan. 3). Persepsi harga berpengaruh positif dan signifikan terhadap kepuasan pelanggan, sehingga semakin baik persepsi harga yang dimiliki produk kosmetik merek Oriflame, maka akan semakin tinggi pula kepuasan pelanggan. 4). Kepuasan pelanggan berpengaruh positif dan signifikan terhadap niat beli ulang, sehingga semakin tinggi kepuasan terhadap produk kosmetik merek Oriflame, maka akan semakin tinggi pula niat beli ulang produknya. 5). Citra merek yang dimiliki produk kosmetik merek Oriflame merupakan variabel yang paling mempengaruhi tingkat kepuasan pelanggan. Citra merek produk Oriflame sebagai produk kosmetik yang berkompeten dan berkualitas, merupakan faktor yang paling mempengaruhi kepuasan pelanggan. 6). Kepuasan pelanggan dapat memediasi variabel citra merek, kualitas produk dan persepsi harga terhadap niat beli ulang, karena nilai t hitung lebih besar dari t tabel yaitu sebesar 1,96, maka variabel mediator kepuasan pelanggan termasuk kedalam mediasi parsial.

Berdasarkan kesimpulan yang telah dipaparkan, beberapa saran yang dapat diberikan baik kepada perusahaan, hasil penelitian ini dapat dijadikan rujukan bagi manajemen pemasaran untuk mengambil keputusan. Hasil penelitian ini menunjukan bahwa kepuasan memiliki nilai rata - rata yang paling terendah yaitu sebesar 4,23 dan indikator keputusan tepat memiliki skor terendah yaitu sebesar 4,21. Sehingga dalam penelitian ini perusahaan harus lebih memperhatikan kepuasan pelanggannya.

Diposisi kedua, kualitas produk berada diposisi kedua terendah yaitu memiliki rata - rata sebesar 4,24 dan indikator kualitas yang dipersepsikan 
Ida Ayu Putu Dian Savitri, Pengaruh Citra Merek, Kualitas Produk...

memiliki skor terendah yaitu sebesar 4,23. Sehingga perusahaan harus lebih memperhatikan kualitas yang dipersepsikan oleh konsumen agar konsumen lebih percaya akan kualitas produk kosmetik merek Oriflame. Diposisi ketiga, niat beli ulang memiliki rata - rata sebesar 4,25 dan indikator niat referensial memiliki rata-rata skor terendah sebesar 4,19. Sehingga perusahaan harus lebih memperhatikan niat referensial agar konsumen dapat lebih merekomendasikan produk kosmetik merek Oriflame kepada orang lain dan konsumen terus berniat untuk membeli ulang.

Hasil rata - rata tertinggi dimiliki oleh variabel citra merek dan persepsi harga yaitu sebesar 4,27. Indikator favorable memiliki skor tertinggi pada citra merek yaitu sebesar 4,33, itu berarti produk kosmetik merek Oriflame mampu mudah diingat oleh konsumennya. Rata - rata yang sama dimiliki oleh variabel persepsi harga yaitu sebesar 4,27 dan indikator yingkat harga yang relatif mempunyai skor tertinggi yaitu sebesar 4,30, itu berarti konsumen menganggap produk kosmetik merek Oriflame memiliki harga yang relatif dengan produk yang didapatkan oleh konsumennya. Kepuasan pelanggan dapat memediasi variabel citra merek, kualitas produk dan persepsi harga terhadap niat beli ulang. Sehingga, faktor terpenting agar pelanggan berniat untuk membeli ulang suatu produk adalah kepuasan.

Bagi peneliti selanjutnya, diharapkan dapat melibatkan responden yang lebih banyak dan cakupan yang lebih luas, sehingga hasil yang didapat lebih akurat dan untuk mengetahui adanya perbedaan hasil atau tidak. 


\section{DAFTAR RUJUKAN}

Alma, Buchari. 2005. Manajemen Pemasaran dan Pemasaran Jasa. Bandung: Alfabeta.

Anggraeni, Dita Putri., Srikandi Kumadji dan Sunarti. 2016. Pengaruh Kualitas Produk Terhadap Kepuasan Dan Loyalitas Pelanggan (Survei pada Pelanggan Nasi Rawon di Rumah Makan Sakinah Kota Pasuruan). Jurnal Administrasi Bisnis, 37(1), 171 - 176.

Adil, Maikul. 2012. The Influence Of Brand Image On Sales. Journal of Basic and Applied Scientific Research. 2(4), $3552-3556$.

Arslan, M. And Zaman. R. 2014. Impact of Dividend Yield and Price Earnings Ratio on Stock Return. Journal of Finance and Accounting. 5(19), 1-8.

Adiputra, Febrian dan Sutopo. 2016. Analisis Pengaruh Kepuasan Dan Persepsi Harga Terhadap Citra Restoran Dan Minat Beli Ulang Pelanggan Holycow Semarang. Jurnal Of Management. 5(1), $1-11$

Beneke, Justin dan Natalia Zimmerman, 2014. Beyond Privat Label Panache : The Effect of Store Image And Perceived Price on Brand Prestige. Journal of Consumer Marketing. 31(4), $301-311$.

Bailia, Jefry F.T, Agus Supandi Soegoto dan Sjendry Serulo R. Loindong. 2014. Pengaruh Kualitas Produk, Harga dan Lokasi Terhadap Kepuasan Konsumen Pada Warung - Warung Makan Lamongan Di Kota Manado. Jurnal EMBA, 2(3), 1768 - 1780.

BPOM. 2013. Peraturan Menteri Kesehatan RI No. 445/Menkes/Permenkes/ 1998. www.pom.go.id. Diakses pada 16 Pebruari 2018.

Consuegra, David Martin, Aeturo Monalia, dan Agueda Esteban. 2007. An Integrated Model of Price Saticfaction and Loyalty : An Empirical Analysis in The Srvice Sector. Journal of Product and Brand Management, 16(7), $459-468$.

Darmawan, Putu Ayu Dessy Trisnadewi, dan Ni Wayan Ekawati. 2017. Pengaruh Kepuasan Konsumen Memediasi Harga Terhadap Loyalitas Konsumen Dalam Berbelanja Pada Florist Online Di Kota Denpasar. E-Jurnal Manajemen Universitas Udayana, 6(4), 2076 - 2104

Denniswara, Edo Praditya. 2016. Pengaruh Kualitas Produk, Harga Dan Promosi Terhadap Intensi Membeli Ulang Produk My Ideas. Jurnal Manajemen dan Start-Up Bisnis, 1(4), 481- 488. 
Ida Ayu Putu Dian Savitri, Pengaruh Citra Merek, Kualitas Produk...

Dharmmesta, Drs. Basu Swastha dan Handoko, Drs. T. Hani. 2000. Manajemen Pemasaran: Analisa Perilaku Konsumen, Edisi Pertama. Yogyakarta: BPFE.

Ferdinand, A.T. 2002. Structural Equation Modeling dalam Penelitin Manajemen. Semarang: Badan Penerbit Universitas Diponogoro Semarang.

Fonseca, Filipa Sofia Pinto, Carlos Brito. 2010. Service Quality and Costumer Satisfaction in Public Transport. International Journal of Quality Research. 4(2), $125-130$.

Fang, Yu-Hui., Chiu, Chao-Min, and Wang, Eric T.G. 2011. Understanding Customers Satisfaction and Repurchase Intentions. Internet Research. 21(4), $479-503$.

Fang, Shan. 2014. Empirical Study of Influential Elements of University Students E-satisfaction. International Journal of Business and Sosial Science.5(6), $122-129$.

Griffin, Ricky W. 2006. Manajemen Edisi Ketujuh Jilid 2. Jakarta: Erlangga.

Hellier, Kotler, P., Geursen, G.M., Carr, R.A., \& Rickard, J.A.2003. Customer Repurchase Intention: A General Structural Equation Model. European Journal of Marketing, 37(11), 1762-133.

Hidayat, Rachmat. 2009. Pengaruh Kualitas Layanan, Kualitas Produk dan Nilai Nasabah Terhadap Kepuasan dan Loyalitas Nasabah Bank Mandiri. Jurnal Manajemen dan Kewirausahaan, 11(1),59-72.

Harjati, Lily dan Yurike Venesia. 2015. Pengaruh Kualitas Layanan Dan Persepsi Harga Terhadap Kepuasan Pelanggan Pada Maskapai Penerbangan Tiger Air Mandala. E- Journal Widya Ekonomika, 1(1), 64 - 73.

Huang, Chun-Chen., Szu-Wei Yen and Cheng-Yi Liu. 2014. The Relationship Among Brand Equity, Customer Satisfaction, And Brand Resonance To Repurchase Intention of Cultural and Creative Industries In Taiwan. The International Journal of Organizational Innovation, 6(3), 106 - 121.

Isabella, Libna dan Amina Sukma Dewi. 2016. Hubungan Persepsi Kualitas, Persepsi Harga, Citra merek dan Persepsi Risiko Dengan Niat Beli Privat Label. Fokus Manajerial Jurnal Manajemen dan Kewirausahaan Universitas Sebelas Maret, 14(2), 115-126.

Iglesias, Marta Pedraja dan M. Jesus Yagile Guillen. 2004. Perceived Quaity and Price: Their Impact on the Satisfaction of Restaurant Customers. 
Internasional Journal of Contemporary Hospital Management, 16(6), 373 379.

Janiszewski, Chris and Marcus Cunha, Jr. 2004. The Influence of Price Discount Framing on The Evaluation of Product Bundle. Journal of Consumer Research, 30(4), 534-546.

Kotler, Philip and Kevin Lane Keller. 2009. Manajemen Pemasaran Edisi Ketiga Belas Jilid 1. Jakarta: Erlangga.

Koubaa, Yamen. 2008. Country Of Origin, Brand Image Perception, and Brand Image Structure. Asia Pacific of Marketing and Logistics, 20(2), 139-155.

Kotler, Philip dan Gary Amstrong. 2010. Prinsip - Prinsip Pemasaran. Jakarta: Erlangga.

Kautsar, Angga P, Sunu Widianto, Rizky Abdulah, dan Hesti Amalia. 2012. Relationship of Consumer Involvement, Credibility of the Source of Information and Consumer Satisfaction on Purchase Decesion of NonPrescription Drugs. Social and Behavioral Science, 65(1), 449 - 454.

Kurniawati, D., Suharyono., Kusumawati, A. 2014. Pengaruh Citra Merek dan Kualitas Produk terhadap Kepuasan dan Loyalitas Pelanggan. Jurnal Administrasi Bisnis, 14(2). 125-132

Lin, Nan-Hong and Bih-Syah Lin. 2007. The Effect of Brand Image and Product Knowledge on Purchase Intention Moderated by Price Discount. Journal of International Managements Studies, 121-132.

Malhotra, Naresh K. 2006. Riset Pemasaran: Pendekatan Terapan Jilid 1. Jakarta:Indeks.

Margaretha, Ardhanari. 2008. Customer Satisfication Pengaruhnya Terhadap Brand Preference dan Repurchase Intention Privat Brand. Jurnal Riset Ekonomi dan Bisnis. 8(2),58-68.

Montung, Pamela, Jantje Sepang dan Decky Adare. 2015. Pengaruh Kualitas Produk, Kualitas Layanan dan Persepsi Harga Terhadap Kepuasan Pelanggan Di Restoran Kawan Baru. Jurnal Berkala Ilmiah Efisiensi, 15(5), 678-689.

Mulyono, Bayu Hadyanto, Yoestini, Rini Nugraheni dan Mustofa Kamal. 2007. Analisis Pengaruh Kualitas Produk Dan Kualitas Layanan Terhadap Kepuasan Konsumen (Studi Kasus Pada Perumahan Puri Mediterania Semarang). Jurnal Studi Manajemen dan Organisasi Universitas Diponogoro, 4(2), 91 - 100. 
Ida Ayu Putu Dian Savitri, Pengaruh Citra Merek, Kualitas Produk...

Moraga, Eduardo Torres, Arturo Z. Vasques Parraga dan Jorge Zamora Gonzales. 2008. Costomer Satisfaction and Loyalty : Start With The Product, Culmite With The Brand. Journal of Consumer Marketing, 25(5), 302 - 33.

Maria, Monica dan Anshoori Yusak Mohamad. 2013. Pengaruh Kualitas Produk Dan Kualitas Layanan Terhadap Kepuasan Konsumen King Cake. Jurnal Manajemen Teori dan Terapan. 6(1), 1-9..

Nigam, A., and Kaushik, R. 2011. Impact of Brand Equity on Costomer Purchase Decisions: an Empirial Investigation with Spesial Reference to Hatchback Car Owners in Central Harayana. IJCEM International Journal of Computational Engineering and Management, 12, 121 - 128.

Nila Kasuma Dewi, Gus Andri, dan Sepris Yonaldi. 2012. Pengaruh Iklan, Citra Merek, Dan Kepuasan Konsumen Terhadap Loyalitas Konsumen Dalam Menggunakan Vaseline Hand And Body Lotion. Di Kota Padanv (Studi Kasus Di Pt. Unilever Cabang Padang). Jurnal Manajemen dan Kewirausahaan. 3(2), 1253-1266

Nurlinda, R.A. 2013. Pengaruh Costomer Satisfaction Strategy Terhadap Peningkatan Kepuasan Konsumen. Forum Ilmiah, 10(2), 172 - 181.

Peter, J. Paul and Jerry C. Olson. 2000. Consumer Behavior: Perilaku Konsumen dan Strategi Pemasaran Jilid 1 Edisi Keempat. Jakarta: Erlangga.

Pusparani, Putu Ayu Yulia dan Ni Made Rastini. 2014. Pengaruh Kualitas Produk dan Citra merek Terhadap Kepuasan Konsumen dan Loyalitas Pelanggan Kamera Canon Digital Single Lens Reflex (DSLR) Di Kota Denpasar. EJurnal Manajemen Universitas Udayana, 3(5), 1311-1319.

Puspasari, Anita. 2014. Pengaruh Kualitas Produk Terhadap Word Of Mouth Melalui Kepuasan Pelanggan. Jurnal Ilmu Manajemen, 2(4), 1737- 1748.

Punamasari, Yulia. 2015. Pengaruh Kualitas Produk Dan Harga Terhadap Kepuasan Konsumen Pproduk M2 Fashion Online Di Singaraja Tahun 2015. Jurnal Jurusan Pendidikan Ekonomi (JJP), 5(1), 1 - 12.

Palma, Marisa Arnindita dan Anik Lestari Andjarwati. 2016. Pengaruh Kualitas Produk, Kemudahan, Dan Harga Terhadap Niat Beli Ulang Dengan Kepuasan Sebagai Variabel Intervening. Jurnal Riset Ekonomi dan Manajemen, 16(1), 84-104.

Prastiwi, Septi K. 2016. Menguji Faktor - Faktor yang Berpengaruh Terhadap Repurchase Intention Pada Produk Mie Instant Indomie Di Yogjakarta. Jurnal EKA CIDA, 1(1), 96 - 109. 
Resti, Devi dan Harry Soesanto. 2016. Pengaruh Persepsi Harga, Kualitas Pelayanan Melalui Kepuasan Pelanggan Terhadap Minat Beli Ulang Pada Rumah Kecantikan Sifra Di Pati. Diponegoro Journal of Management, 5(1), $1-12$.

Ruswanti, Endang. 2011. Pengaruh Pemasaran Kemitraan Terhadap Keunggulan Bersaing. Jurnal Ekonomi, 2(1), 17 - 24.

Riduwan dan Engkos Ahman Kuncoro. 2008. Cara Menggunakan dan Memaknai Analisis Jalur (Path Analysis).Bandung: Alfabeta.

Roring, B.C., Mekel. P.A., dan Soegoto, A.S. 2014. Pencitraan Merk, Penetapan Harga dan Inovasi Produk Pengaruhnya Terhadap Loyalitas Konsumen Dalam Membeli Mobil Toyota Avanza Di Kota Manado. Jurnal EMBA: 2(3), $1225-1236$.

Shimp, Terence A. 2014. Komunikasi Pemasaran Terpadu dalam Periklanan dan Promosi Edisi 8. Jakarta: Salemba Empat.

Sugiyono. 2016. Metode Penelitian Administratif Dilengkapi Dengan Metode $R \& D$. Bandung: Alfabeta.

Susanti, Ni Putu Hani dan I Made Wardana. 2015. Pengaruh Kualitas Produk dan Citra Merek Terhadap Kepuasan dan Loyalitas Pelanggan Pada Produk Kosmetik Hijau Merek The Body Shop. E- Jurnal Manajemen Universitas Udayana, 4(5), 622-636.

Schiffman, Leon G and Leslie L. Kanuk. 2004. Consumer Behavior. Eight Edition. New Jersey: Pearson Education, Inc.

Suryana, Popo dan Dasuki, Eliyandi S. 2013. Analisis Faktor yang Mempengaruhi Keputusan Pembelian dan Implikasinya Pada Minat Beli Ulang, Trikonomika, 12(2), $190-200$.

Sulastri, Tuti. 2017. Pengaruh Kualitas Layanan dan Persepsi Harga Terhadap Kepuasan Mahasiswa Serta Implikasinya Pada Citra Perguruan Tinggi. Jurnal Inspirasi Bisnis dan Manajemen, 1(1), 41-52

Sulistiyanto, F.X dan Euis Soliha, Pengaruh Persepsi Harga, Citra Perusahaan dan Citra Merek Terhadap Kepuasan dan Loyalitas Pelanggan Pada Apotek "Dela" Semarang. Simposium Prosiding Seminar Nasional and Call For Paper Kinerja Perbankan, Bisnis Dan Ekonomi Indonesia Menghadapi ASEAN Economic Community 2015, 25 - 30 Oktober 2016.

Tariq, M.I., M.R. Nawaz, M.M Nawaz, Hasim Awaiz Butt. 2013. Customer Perception About Branding And Purchase Intention : A Study of Fincgin An 
Ida Ayu Putu Dian Savitri, Pengaruh Citra Merek, Kualitas Produk...

Emerging Market. Journal of Basic and Applied Scientific Research, 3(2), $340-347$.

Wirawan, Nata. 2002. Cara Muda Memahami Statistik 1 (Statistik Deskriptif) Edisi 1. Denpasar: Keraras Emas.

Walley, Keith., Paul Custance and Sam Taylor. 2007. The Importance of Brand in The Industrial Purchase Decision: A Case Study of The UK tractor market. Journal of Business and Industrial Marketing, 22(6), 383 - 393.

Wijaya, Surya dan Nurcaya, Nyoman. 2017. Kepuasan Pelanggan Memediasi Kualitas Produk Dan Kewajaran Harga Terhadap Loyalitas Merek Mcdonals Di Kota Denpasar. E-Jurnal Manajemen Unud, 6(3), 1 - 30.

Yamit, Zulian. 2013. Manajemen Kualitas Produk dan Jasa. Yogyakarta: Ekonisia.

Yaqian, Z. 2011. The Impact of Custumer Based Brand Equity on Revisit Intentions: An Empiriical Study of Five Shanghai Budget Hotels. AU-GSB E- Journal (Online). 4(1), 168 - 181.

Yana, Ravita Dwi, Syharyono dan Yusri Abdillah. 2015. Pengaruh Citra Merek Terhadap Kepuasan Pelanggan Dan Loyalitas Pelanggan (Survei Pada Konsumen Produk Busana Muslim Dian Pelangi Di Malaysia). Jurnal Administrasi Bisnis (JAB). 21(1), 1-7. 